\title{
Acheulean Bifaces from Khor Shambat, Omdurman (Sudan), Comparative Studies in the Nubian Context ${ }^{1}$
}

\author{
Mirosław Masojéc $^{a}$, Amel Hassan Gismallah ${ }^{b}$, Grzegorz Michalec $^{c}$, \\ Andrzej Gałaś ${ }^{d}$ and Maciej Jórdeczka ${ }^{e}$
}

\begin{abstract}
This work presents Acheulean material discovered in Khor Shambat (Omdurman, Sudan), situated on the left-bank Nile valley a few $\mathrm{km}$ north of Khor Abu Anga and about $7 \mathrm{~km}$ from the Nile valley, ro $\mathrm{km}$ to the north-west of the confluence of the Blue and White Nile. The artefacts occur randomly in the channel or in the channel deposit, the latter forms elongated bars composed of fluvial deposits with a low degree of sorting. The assemblage consists of 34 artefacts made from highly eroded Nubian sandstones. The most common shape of the hand-axe from Khor Shambat is the cordiform type with lenticular cross section made on a chunk or cobble. The hand-axes from Khor Shambat were subject to a morphometric analysis together with the assemblage from two other Nubian Acheulean sites. The geometric-morphometric approach to 2D objects attempted to identify differences between the assemblages. The broad chronology of the Acheulean proposed for Khor Abu Anga by Roy L. Carlson might potentially be applicable to the Khor Shambat assemblage, which may fall within the range of $350-200 \mathrm{ka}$.
\end{abstract}

KEY-WORDS: Acheulean, hand-axes, Khor Shambat, Dakhla Oasis, EDAR

a University of Wroclaw, Institute of Archaeology, Laboratory for Non-European Archaeology, Szewska Street 48, 50-139 Wroclaw, Poland; e-mail: miroslaw.masojc@uwr.edu.pl; ORCID: 0000-0001-7779-5014

$b$ National Corporation for Antiquities and Museums, Sudan Ministry of Culture and Tourism, P. O. B. I78, Khartoum IIII5, Sudan; e-mail: amel2oooh@yahoo.co.uk; ORCID: 0000-0003-0102-1295

c University of Wroclaw, Institute of Archaeology, Szewska Street 48, 50-I39 Wroclaw, Poland; e-mail: grzesiek.michalec@gmail.com; ORCID: 0000-0002-5794-5334

d AGH University of Science and Technology, Faculty of Geology, Geophysics and Environmental Protection, Al. Mickiewicza 30, 30-059 Cracow, Poland; e-mail: pollux@geol.agh.edu.pl; ORCID: 0000-0003-0083-3769

$e$ Institute of Archaeology and Ethnology, Polish Academy of Sciences, Rubież Street 46, 6I-6I2 Poznan, Poland; e-mail: maciej.jordeczka@iaepan.poznan.pl; ORCID: 0000-0002-5026-4528

1 This paper is funded by the National Science Centre, Poland a government agency supervised by the Ministry of Science and Higher Education (NCN 2015/19/B/HS3/03562). Andrzej Gałaś and Maciej Jórdeczka were supported by the National Science Centre, Poland (NCN 2015/17/D/HS3/01492). 
40 Mirostaw Masojć, Amel Hassan Gismallah, Grzegorz Michalec, Andrzej Gataś and Maciej Jórdeczka

\section{INTRODUCTION}

In his pioneering work from 1949, A. J. Arkell mentions two Acheulean sites in the vicinity of Omdurman; the first was situated in Khor Abu Anga - a left-bank tributary flowing into the Nile, $c . \mathrm{km}$ to the north of the confluence of the Blue Nile and White Nile - and the other was situated in Wadi Siru - a left-bank valley joining the Nile c. $15 \mathrm{~km}$ to the north of their confluence (Arkell 1949).

More recently, extensive research at the Abu Anga site (Carlson 2015, there earlier literature devoted to the site) has revealed much about the context of the site and the material from it. The site is connected with the channel of an intermittent river (wadi, tributary of the Nile) cut through a substratum of Nubian sandstones. The fluvial deposits are predominantly gravel and bank gravel of various sizes connected with periodic, uncontrolled water flows. Trial trenches at the site revealed the changes of the river's channel typical of intermittent rivers, as well as the presence of deposits connected with stagnant water, e.g., a lens of brown silt (38I-382 m a.s.l.). According to Carlson (20I5), the latter is connected with one of the floodings of the Nile, which reached several $\mathrm{km}$ along such shallow channels. On both sides of the high bank of the Abu Anga channel occur younger layers of distinctly laminated silt interleaved with fine-grained gravel (thickness of individual layers $\mathrm{I}-40 \mathrm{~cm}$ ). They are relatively

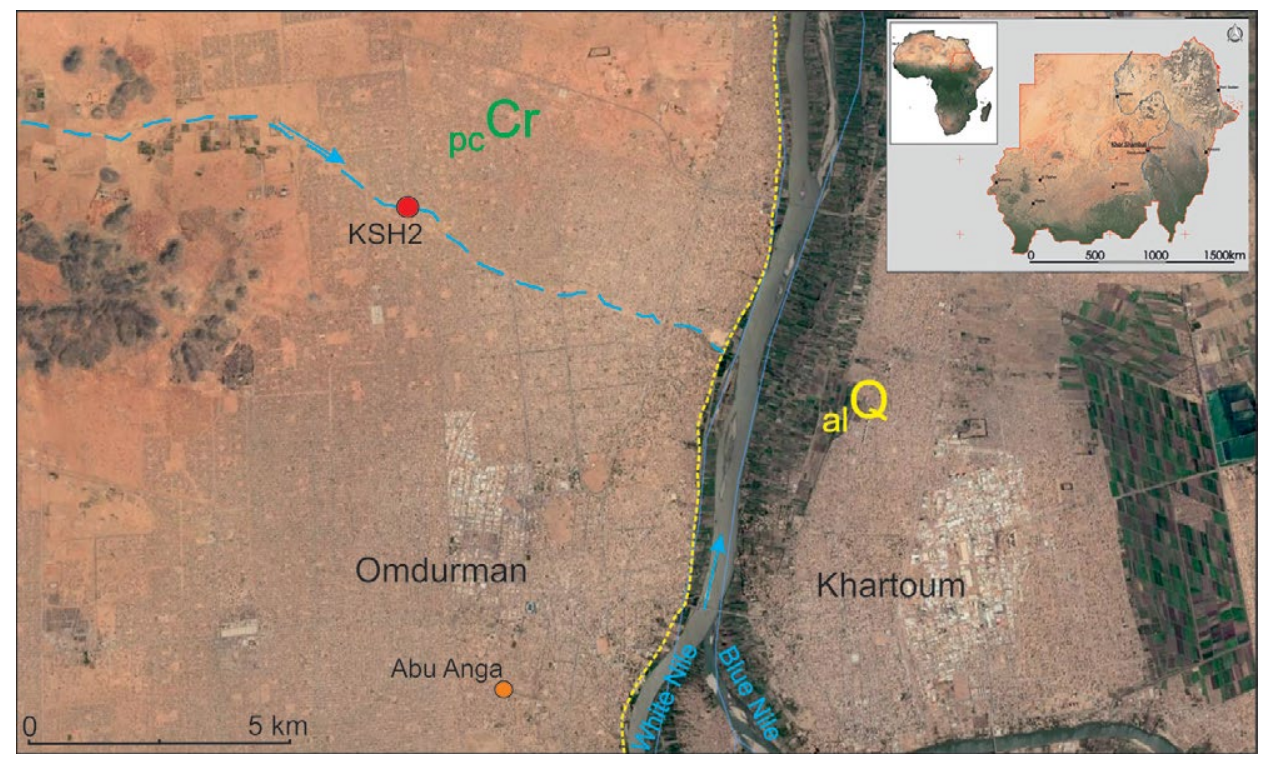

Fig. I. Khor Shambat in Omdurman. Site no. 2 within the khor, whose course is marked with dotted line; alQ - Holocene alluvia of Nile; pcCr - Cretaceous Nubian Sandstones.

Location of the Abu Anga site according to Carlson (2015). 
Acheulean Bifaces from Khor Shambat, Omdurman (Sudan), Comparative Studies in the Nubian Context $\mid$

young deposits connected with climatic cycles - dry/wet season in the Nile valley (Carlson 20I5).

This paper aims to present the Acheulean material also discovered in Omdurman, in another left-bank valley between the two sites mentioned above. This third site, Khor Shambat, is over Io km to the north-west of the confluence between the Blue Nile and White Nile and $c .7 \mathrm{~km}$ from the Nile valley, and it is of similar nature to the abovementioned Abu Anga site (Fig. I). The material discussed here has not been discussed in the previous monographic studies of Pleistocene cultures in Sudan published so far (Arkell 1949; Idris 1994).

\section{KHOR SHAMBAT}

Several years ago, a collection of Acheulean artefacts from Khor Shambat was handed over to the National Corporation for Antiquities and Museums (NCAM) in Khartoum by an anonymous researcher. There are no precise data about the objects' original location within the stated findspot. Verification field work of the area carried out in 2014 and 2019 confirmed the occurrence of single Acheulean artefacts in fluvial deposits marked as Khor Shambat site 2 (KHS2). In addition, individual artefacts from the Middle Stone Age (MSA) were also found.

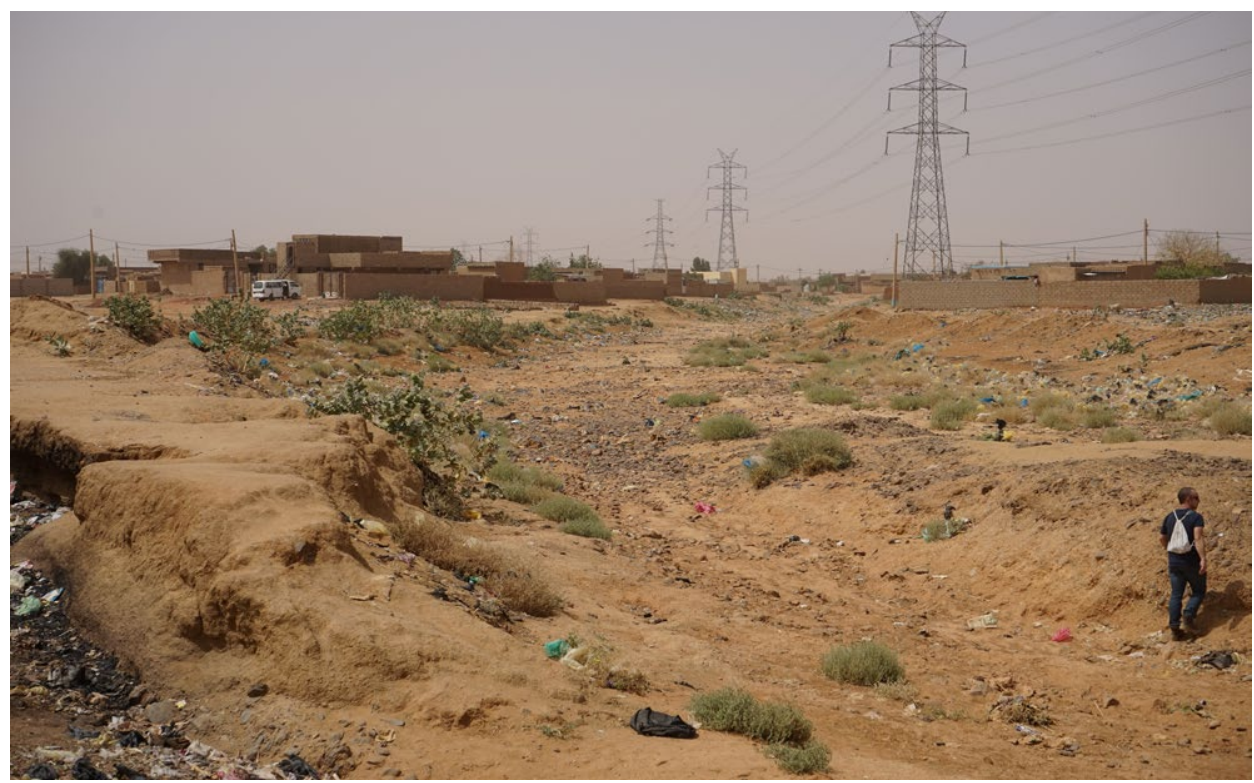

Fig. 2. Khor Shambat at the location of site no. 2. Photo: M. Masojć. 
42 Mirostaw Masojć, Amel Hassan Gismallah, Grzegorz Michalec, Andrzej Gataś and Maciej Jórdeczka

The area where Acheulean artefacts occur is close to a Mesolithic and Neolithic site (Khor Shambat site 1) situated at the edge of a seasonal or dry watercourse (khor) at its outlet (Jórdeczka et al., 2020). In the same channel is the area of occurrence of these artefacts, denoted as Khor Shambat 2 (general area $15^{\circ} 43^{\prime} 17.28 " N, 32^{\circ} 27^{\prime} 13.63^{\prime E}$ ). This site is situated within the intermittent river valley (Fig. 2) constituting a left-bank tributary of the Nile. The valley cuts through the spacious surface of a sandstone outcrop known as the Butana plain. The area's substratum is (Cretaceous) Nubian sandstone, which reaches a thickness of 300-500 m (Whiteman 197I) and overlies the Arabian-Nubian shield (Neoproterozoic). According to archival sources (Robertson et al., 1988), the Nubian sandstone is covered by the Ruwaba Formation composed of silty sand and gravel deposits.

Field evidence shows that the Acheulean artefacts occur randomly in the channel or in the deposit, the latter forms elongated bars composed of fluvial deposits with low degree of sorting (Fig. 3, 4). Meandering gently, the channel has mostly a relatively even
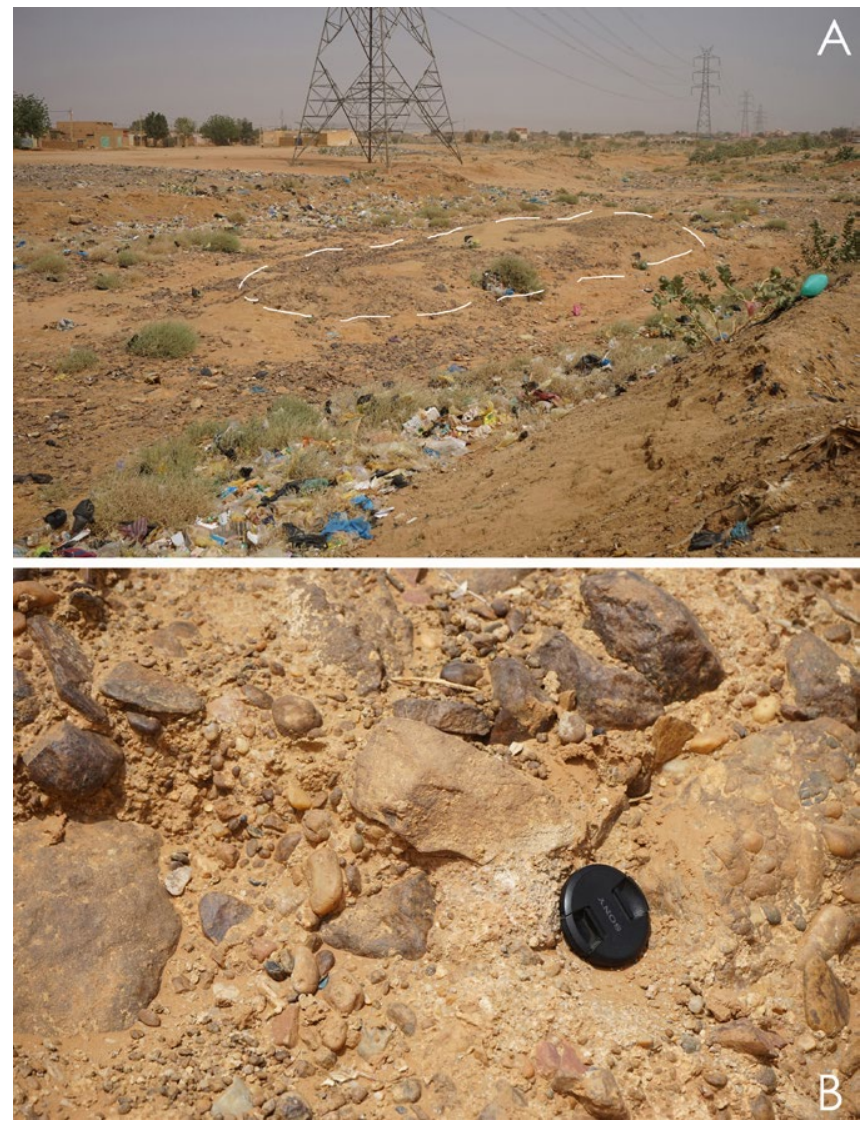

Fig. 3. Khor Shmabat, site 2. A - elongated bars composed of fluvial deposits (marked with white dotted line) within which Palaeolithic artefacts occur; B - Acheulean hand-axe in the fluvial deposit. Photo: M. Masojć. 
and flat bottom covered with quartz and sandstone gravel mixed with sandstone chunks with uncoated surface. There is a considerable contribution of coarse-grained sand and silt in the deposits. They also include an accumulation of big sandstone blocks and ferruginous mudstones, fine-grained gravels and silt formations. In several places, a layer of gravels composed of coated grains of quartz, quartzites and quartz sandstones with a high degree of sorting can be clearly distinguished under the big, relatively uncoated sandstone chunks and blocks. These are deposits typical of the alluvial channel fraction and testify to the sudden process of creation, e.g., torrential downpour or flood. They may form as a result of the erosion of sandstone outcrops, caliche layers, broken up and subsequently carried by the river. The artefacts found in this deposit (Fig. $3 \mathrm{~B}, 4$ ) come from the drainage area of the intermittent river and were transported by water during flows caused by torrential rain. The transport could have taken place in a few stages caused by increased downpour separated by dry periods or low water levels.

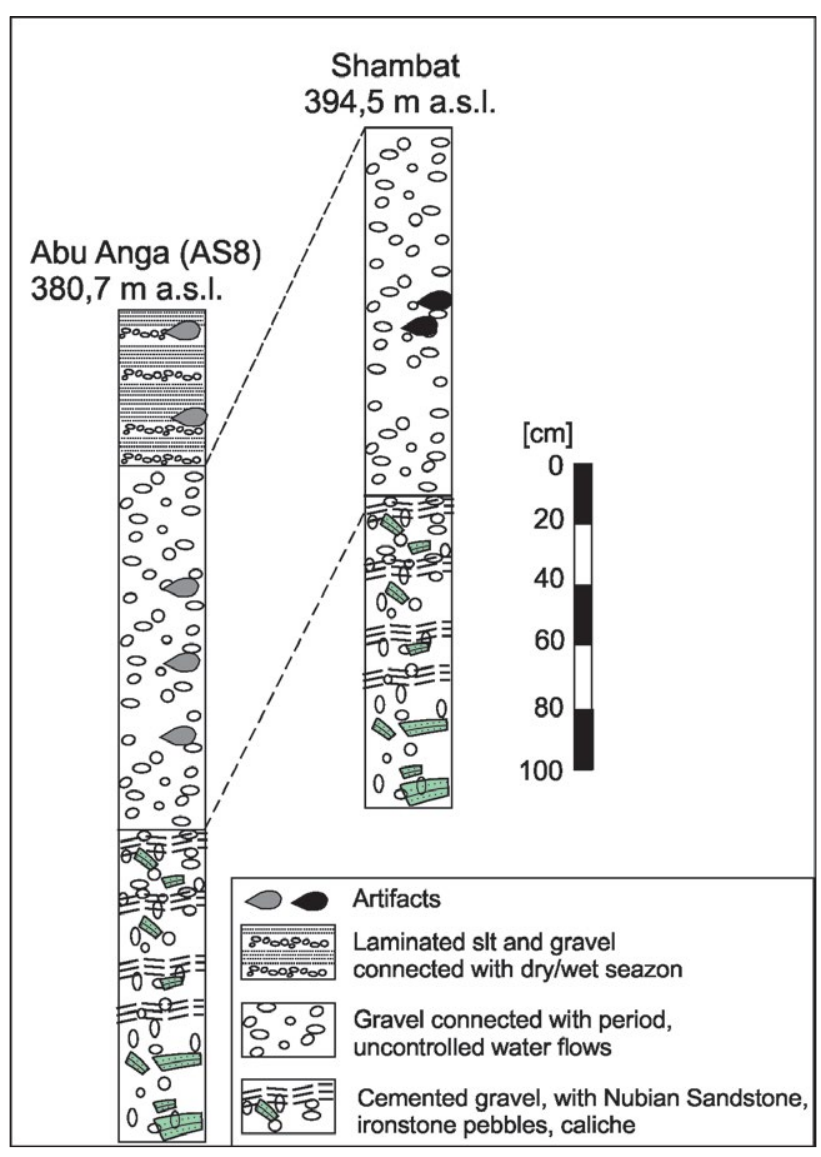

Fig. 4. Lithological sections with the position of occurrence of artefacts. Khor Abu Anga section after Carslon 20I5. Drawn: A. Gałaś. 
44 Mirostaw Masojć, Amel Hassan Gismallah, Grzegorz Michalec, Andrzej Gataś and Maciej Jórdeczka
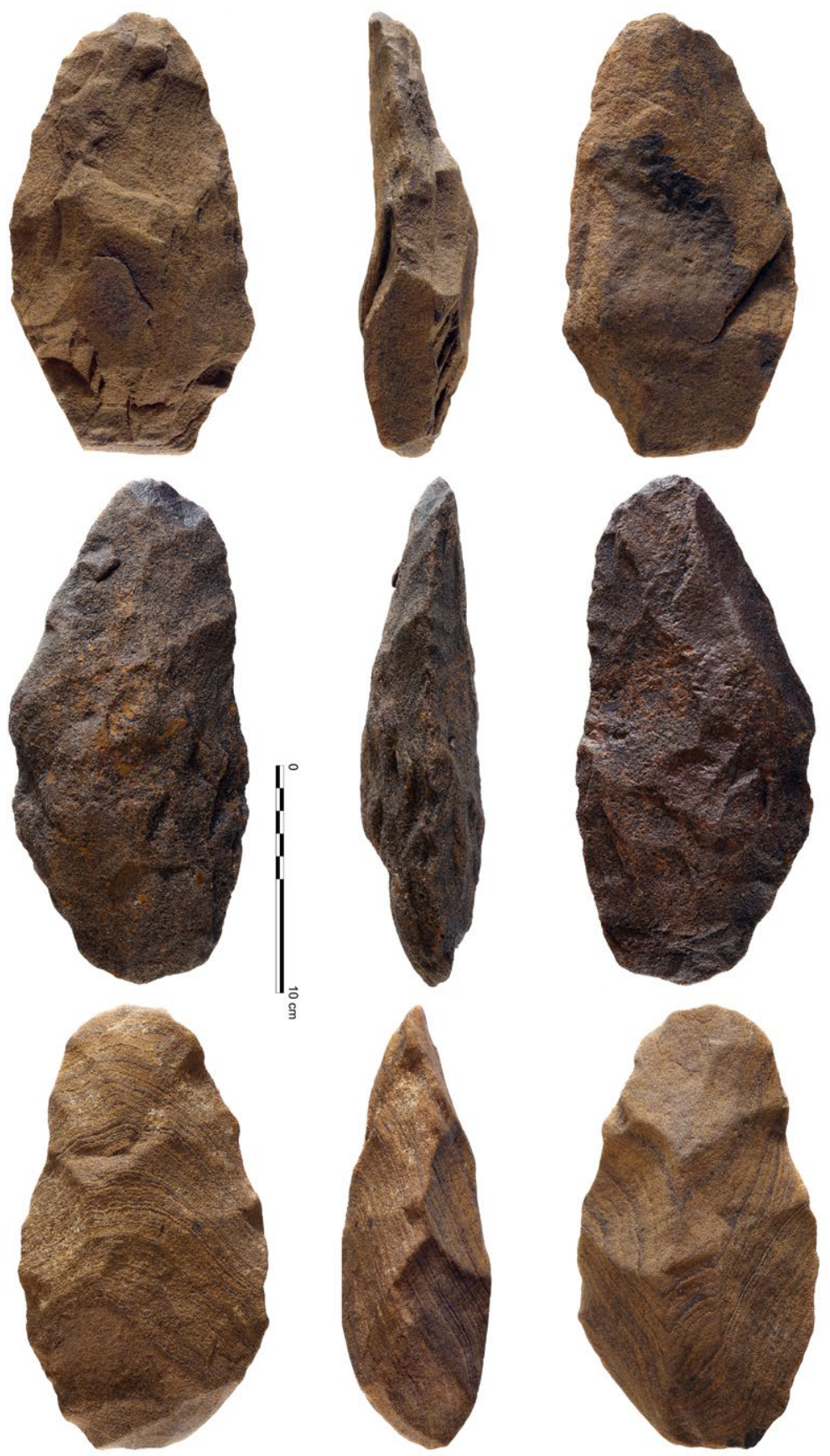

Fig. 5. Khor Shambat, site 2. Hand-axes. Photo: M. Jórdeczka. 
Acheulean Bifaces from Khor Shambat, Omdurman (Sudan), Comparative Studies in the Nubian Context
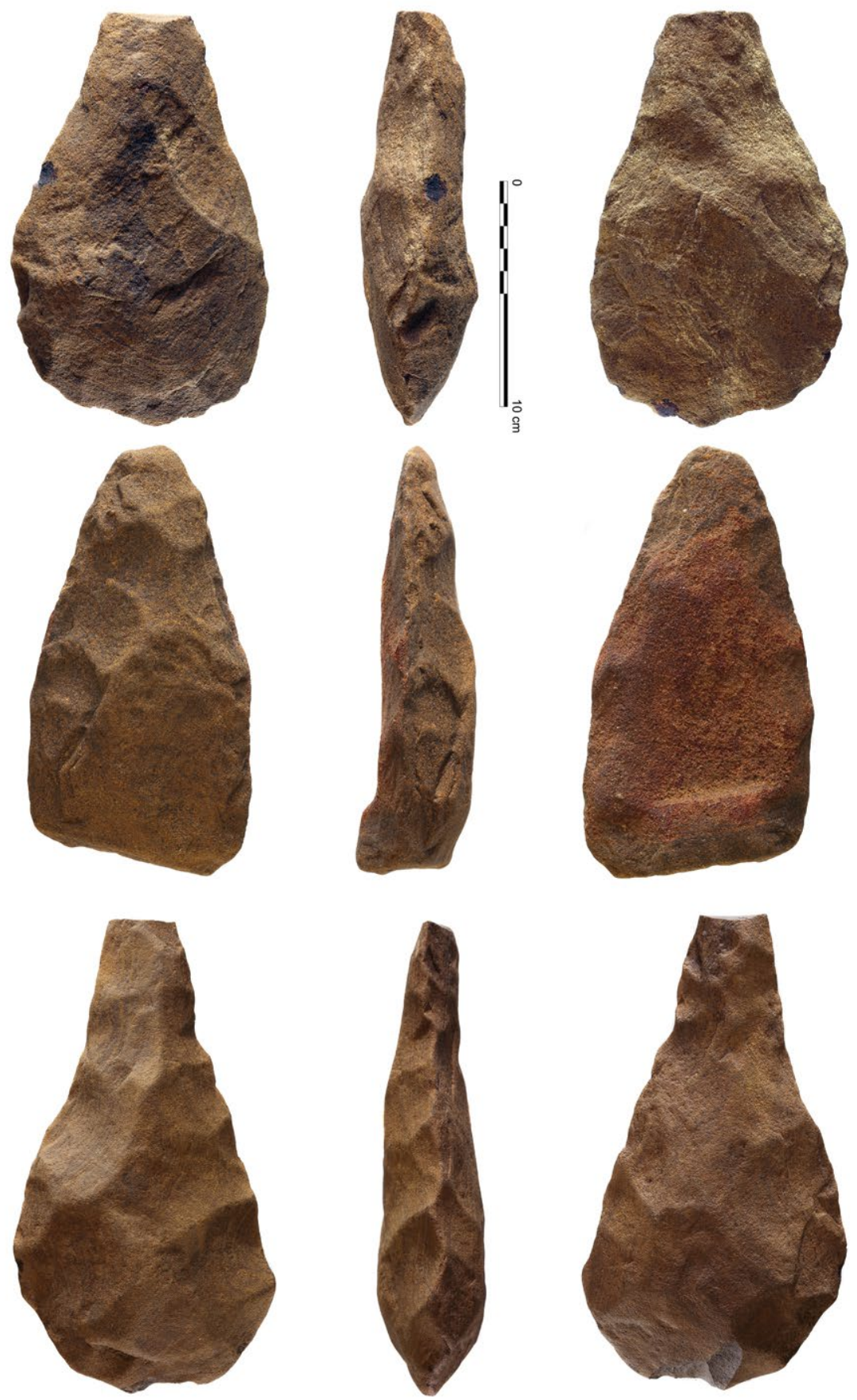

Fig. 6. Khor Shambat, site 2. Hand-axes. Photo: M. Jórdeczka. 
46 Mirostaw Masojć, Amel Hassan Gismallah, Grzegorz Michalec, Andrzej Gataś and Maciej Jórdeczka
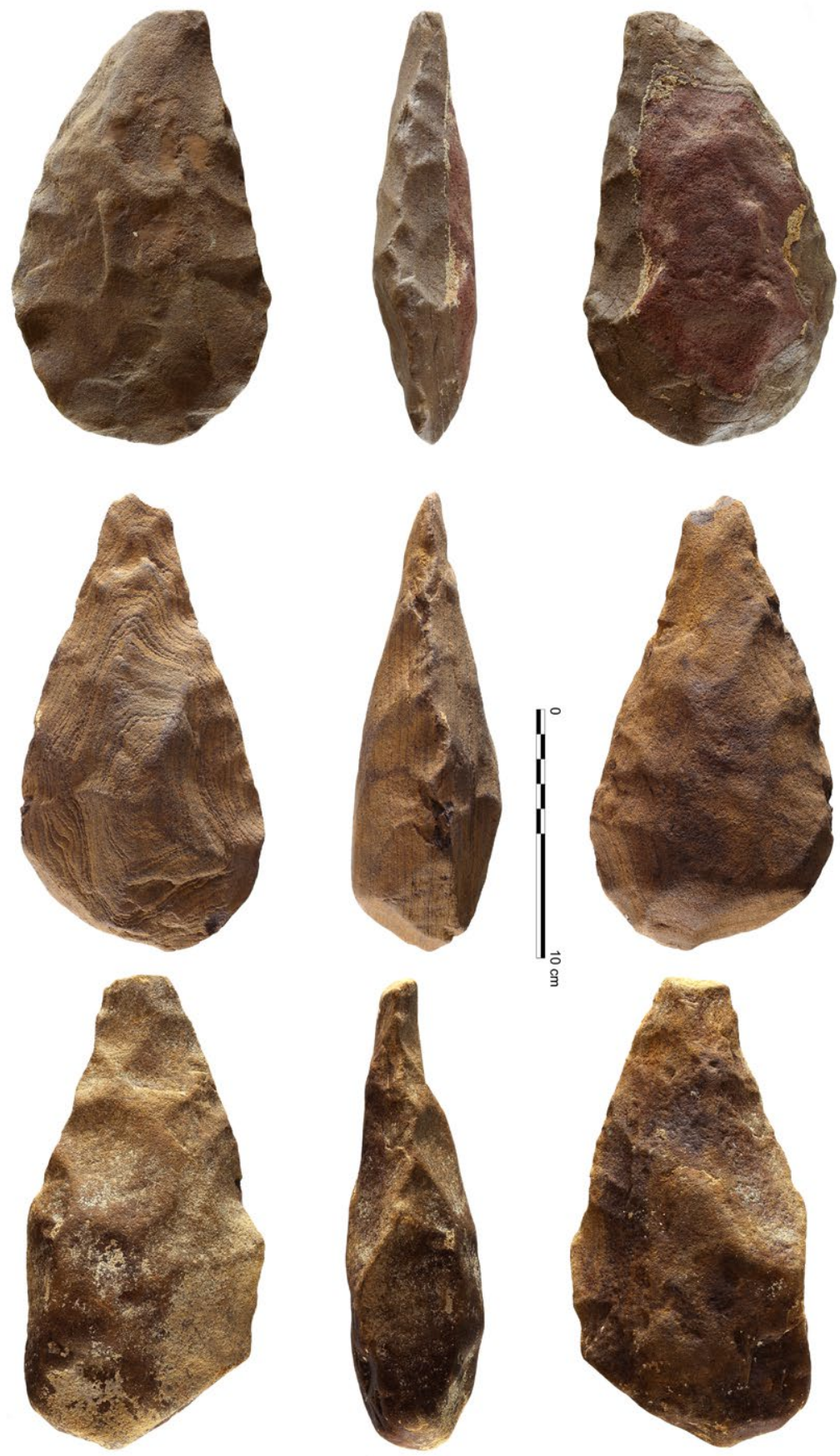

Fig. 7. Khor Shambat, site 2. Hand-axes. Photo: M. Jórdeczka. 
Acheulean Bifaces from Khor Shambat, Omdurman (Sudan), Comparative Studies in the Nubian Context $\mid 47$
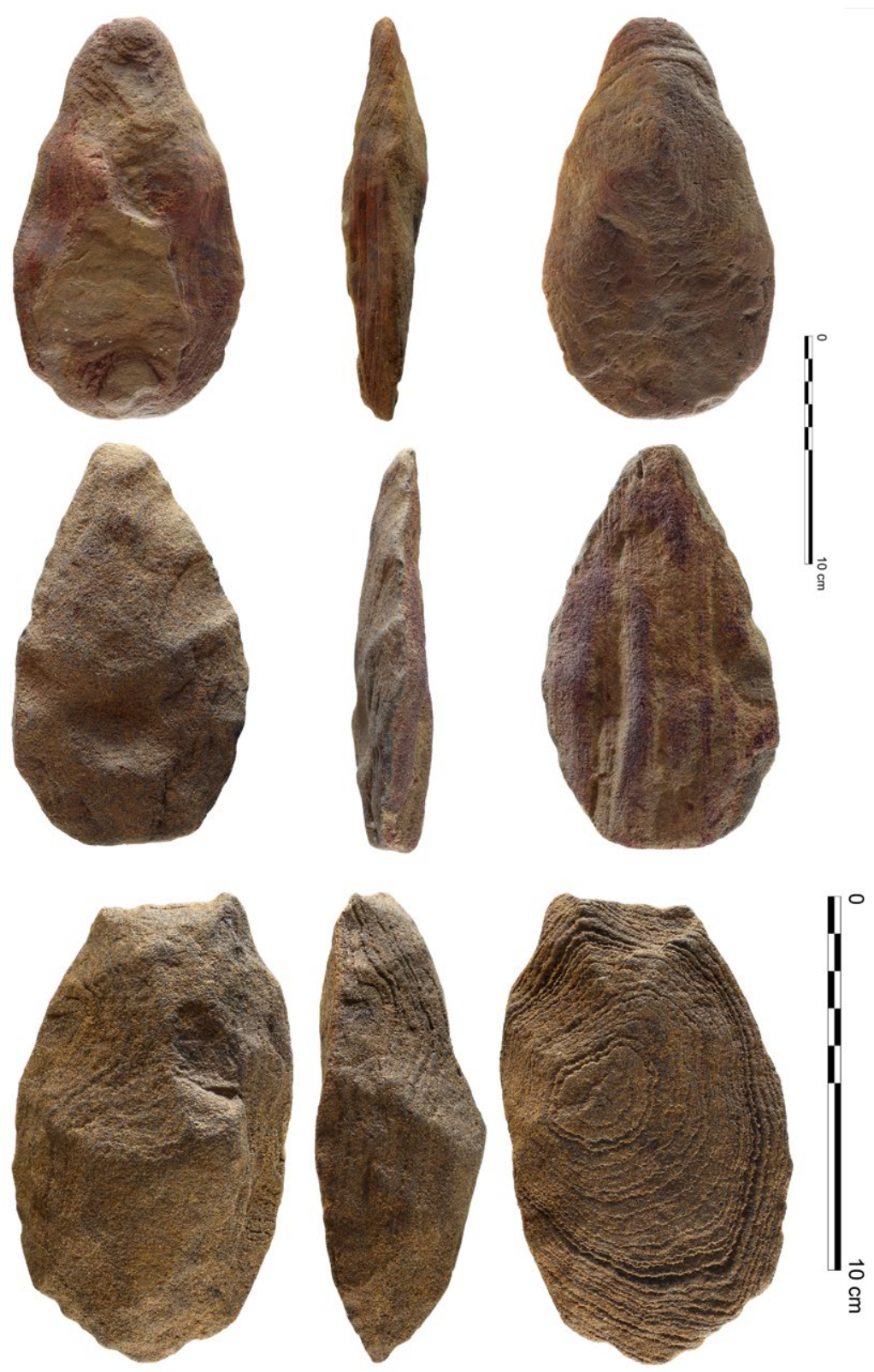

Fig. 8. Khor Shambat, site 2. Hand-axes and cleaver. Photo: M. Jórdeczka. 
48 Mirostaw Masojć, Amel Hassan Gismallah, Grzegorz Michalec, Andrzej Gataś and Maciej Jórdeczka
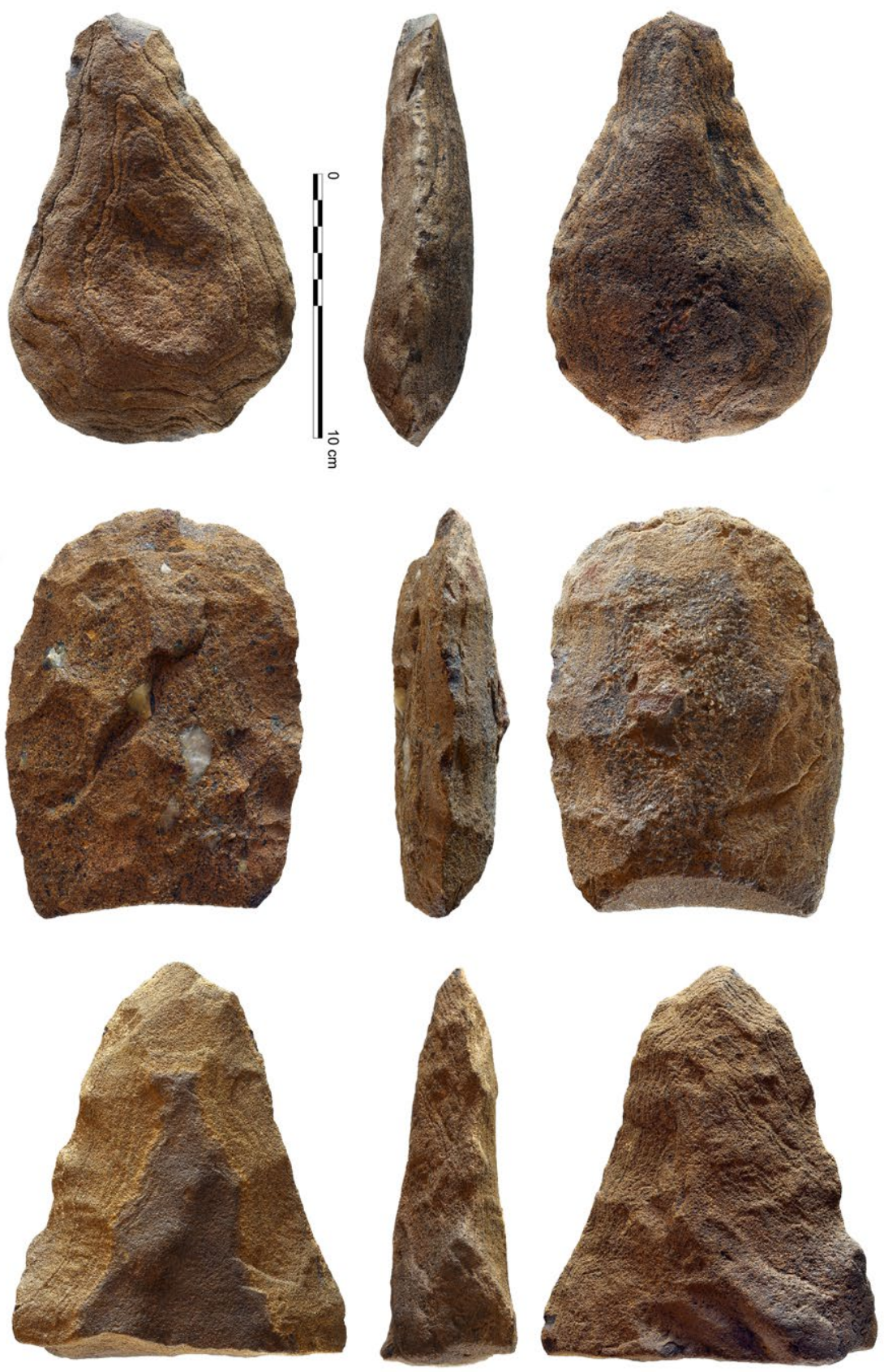

Fig. 9. Khor Shambat, site 2. Hand-axes. Photo: M. Jórdeczka. 

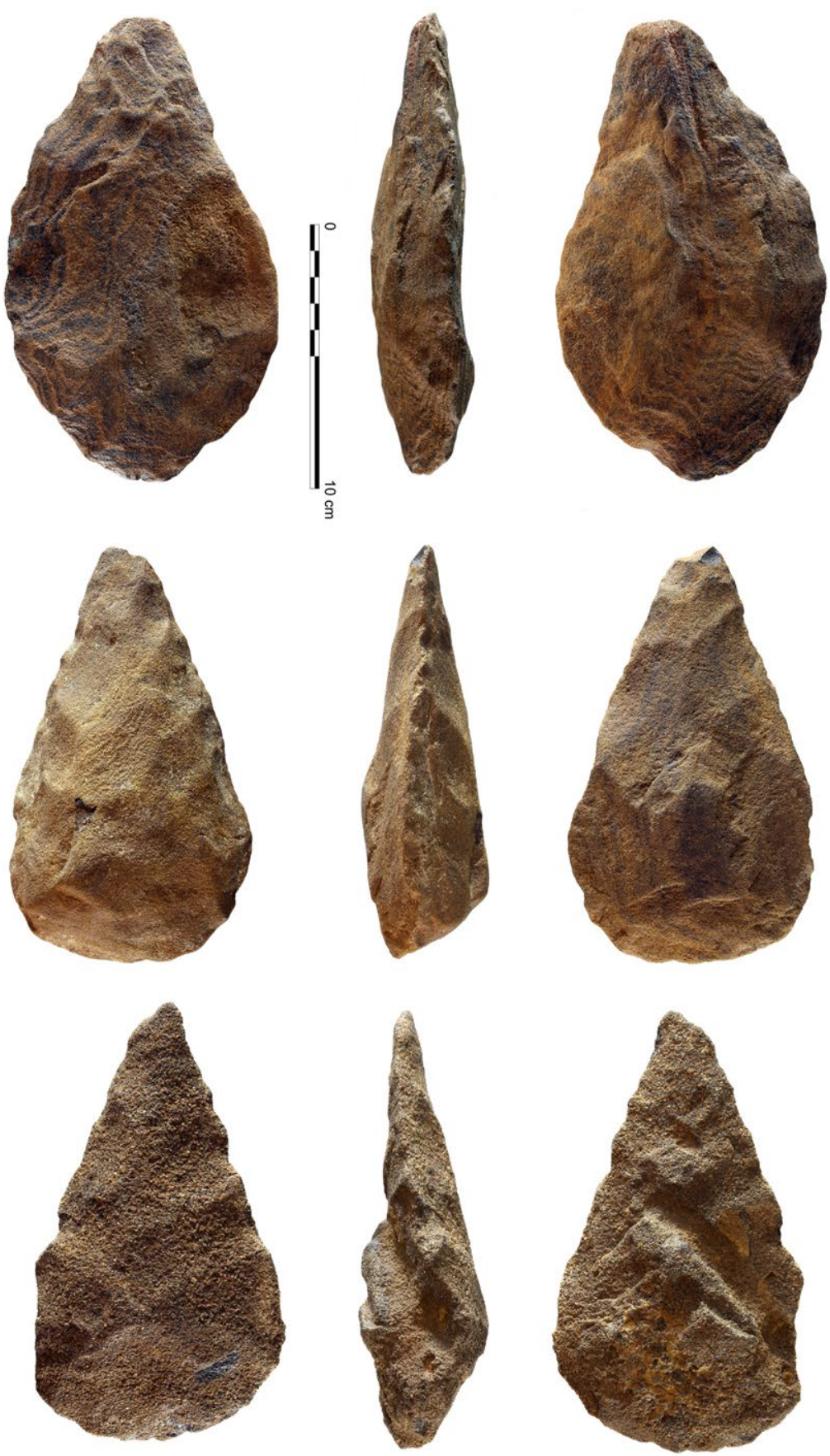

Fig. Io. Khor Shambat, site 2. Hand-axes. Photo M. Jórdeczka. 
50 Mirostaw Masojć, Amel Hassan Gismallah, Grzegorz Michalec, Andrzej Gataś and Maciej Jórdeczka
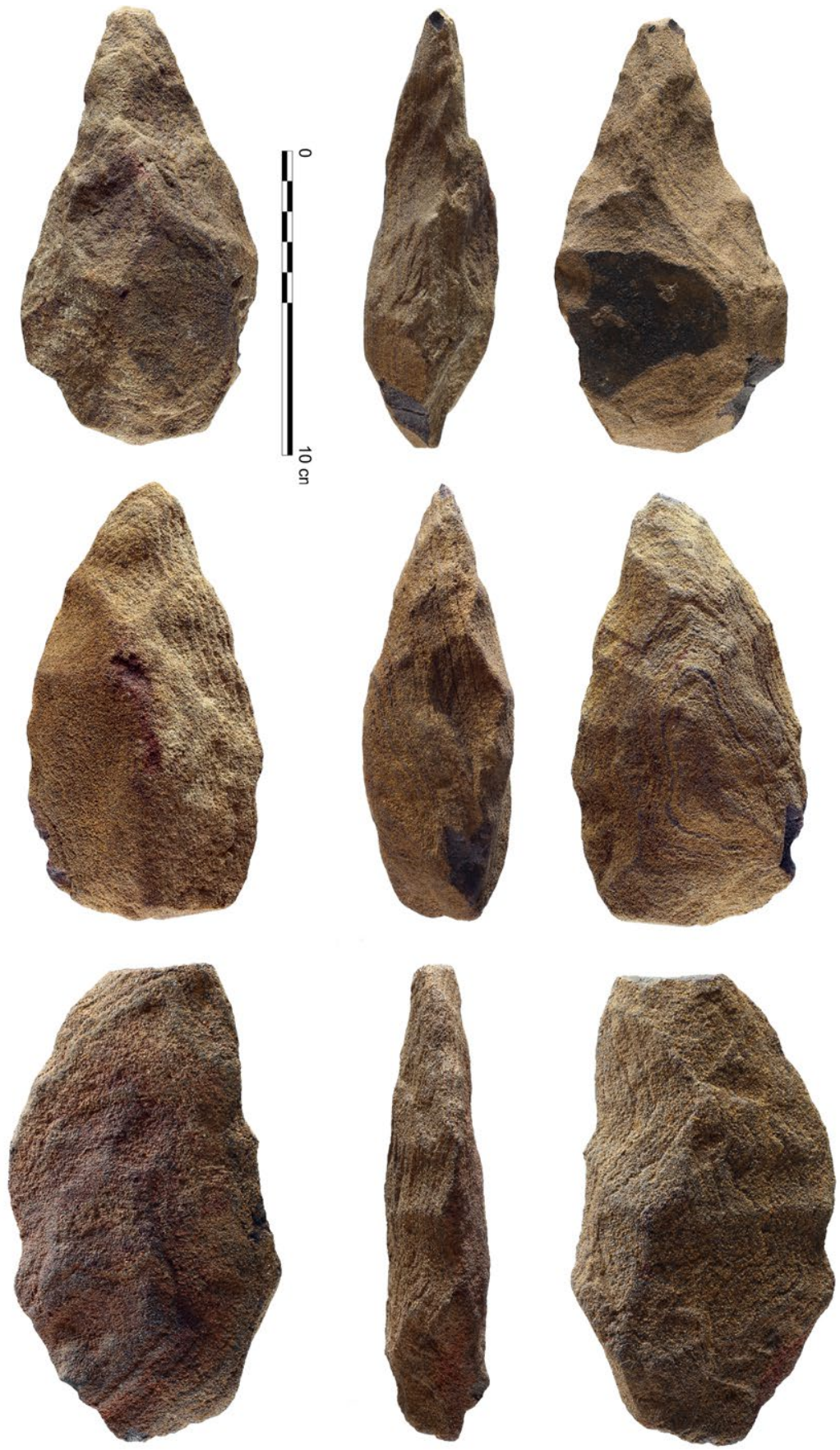

Fig. II. Khor Shambat, site 2. Hand-axes. Photo: M. Jórdeczka. 


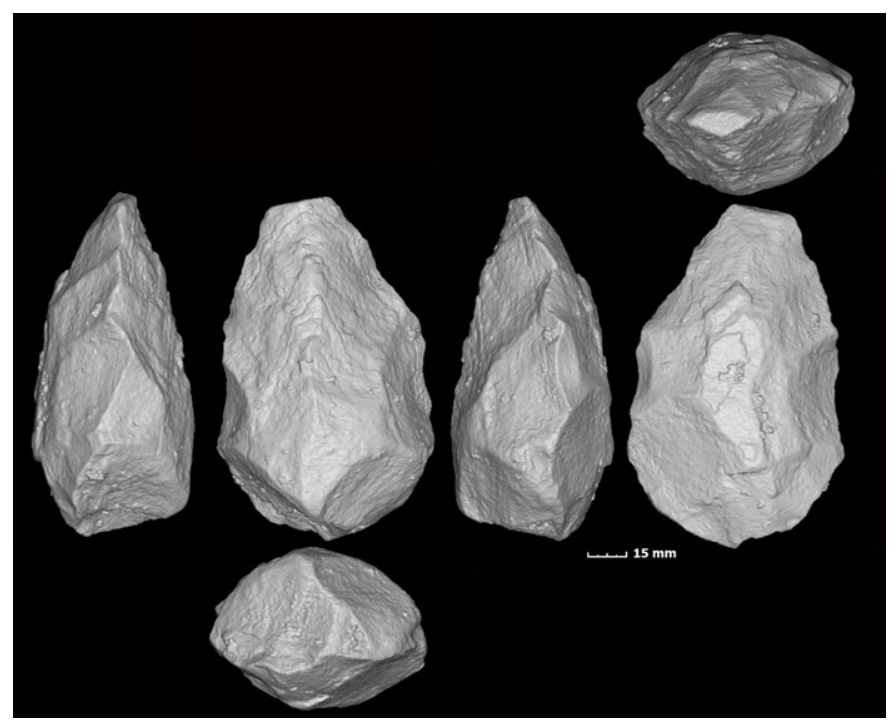

Fig. I2. Khor Shambat, site 2. Hand-axe CT scanned. Scan: G. Ziółkowski.

\section{CHARACTERISTICS OF THE RAW MATERIAL OF THE ARTEFACTS}

The sedimentary rocks used for production of tools were recorded in the site's close vicinity. They are solely Nubian sandstones of ferruginous facies and ferruginous mudstones, which may come from the caliche layer common in the outcrops in Omdurman. Their predominance in the assemblage suggests that they had been acquired on the spot or in the close vicinity. The Nubian sandstones (Cretaceous) of the ferruginous variety are composed of quartz grains and quartz rocks, e.g., quartzites. The binder is ferruginous-argillaceous, mainly goethetic with the presence of hematite. The ferruginous mudstones only locally had a tendency to fracture producing sharp edges, and there were fewer fragments of this stone displaying evidence of use.

\section{THE BIFACIAL COMPONENT FROM KHOR SHAMBAT}

The stone products from Khor Shambat Site 2, were made from eroded Nubian sandstone. The assemblage consists of 34 artefacts, including 27 (79\%) Acheulean large cutting tools (LCT): 24 hand-axes (Fig. 5-I2), one cleaver (Fig. 8) and two biface preforms. The remaining artefacts were three cores, including two Levallois forms, and a discoidal core, assignable to the Middle Stone Age as well as four blanks in the form of flakes, whose attribution remains undetermined. 
52 Mirostaw Masojć, Amel Hassan Gismallah, Grzegorz Michalec, Andrzej Gataś and Maciej Jórdeczka

The great majority of the bifacial forms (LCT) have been preserved in a whole state $(74 \%)$; only one hand-axe is broken in the proximal part, while another six have a slightly broken tip. Table I presents the sizes and weight of the hand-axes and cleaver from Khor Shambat. The length of complete products falls within the range of $\mathrm{II}-22 \mathrm{~cm}$, width $7-12 \mathrm{~cm}$ and maximum thickness is $2.8-6.5 \mathrm{~cm}$. Average weight oscillates around 850 grams (Table I). The total weight of all LCT and 2 preforms: $22424.3 \mathrm{~g}$.

The overwhelming majority of the bifacial components from Khor Shambat had been made on non-flake blanks - 2I out of 24 hand-axes were made on chunks, while only three were probably made on flakes (Fig. 5-II). The only cleaver in the assemblage displays the features of a product made on a flake, while two preforms of hand-axes, similar to most hand-axes, were made on chunks.

For the whole bifacial component, the number of scars on both faces was counted, which testifies to the use of advanced technology in their production. Scars larger than $5 \mathrm{~mm}$ in maximal dimension were counted (smaller scars being treated as retouch). Both for the hand-axes and the cleaver the criterion for distinguishing between face I and face 2 was the extent of advancement of flaking - the more modified side was labelled face I (Goren-Inbar and Saragusti 1996). In the case of face I, the number of flake scars reaches even 24 and their mean number is 15 , which is only slightly more than the number of flake scars in the case of face 2 (Table 2). These values are virtually identical as in the case of the hand-axes from the basalt component in the Acheulean site Gesher Benot Ya'aqov, dated to MIS I8-20 (Goren-Inbar et al., 20I8).

Table I. Dimensions of LCT without biface preforms ( $\mathrm{mm}$ and $\mathrm{g}$ ).

\begin{tabular}{|l|c|c|c|c|c|}
\hline & n & Minimum & Maximum & Mean & Std. deviation \\
\hline Max. length & 18 & 117.3 & 224.0 & 167.6 & 28.2 \\
\hline Max. width & 25 & 71.2 & 127.4 & 97.2 & 13.7 \\
\hline Max. thickness & 25 & 28.5 & 65.9 & 44.5 & 9.9 \\
\hline Weight & 25 & 342.0 & 1508.0 & 866.3 & 317.5 \\
\hline
\end{tabular}

Table 2. Number of scars on both faces of bifacial component.

\begin{tabular}{|l|c|c|c|c|c|}
\hline & n & Minimum & Maximum & Mean & Std. deviation \\
\hline Face 1 - no. of scars & 24 & 11 & 24 & 15.13 & 3.56 \\
\hline Face 2 - no. of scars & 24 & 2 & 19 & 12.46 & 4.09 \\
\hline
\end{tabular}


In contrast to flake scars bigger than $5 \mathrm{~mm}$, some hand-axes display smaller ones, resulting from modification in the form of retouch. Six specimens display bifacial retouch of the edge (intensive retouch on one or both faces), while in three cases thinning of the edge was observed (few scars restricted to the edge and not extensively covering the surface of the biface).

The number of scars on both faces of bifaces is reflected by the presence of natural surfaces. In the case of face I, as many as eight out of 24 hand-axes have no natural surface, while another nine examples have up to $25 \%$ of their natural surface. Seven specimens display up to $50 \%$ of natural surface. The face 2 of bifaces, by definition less modified, displayed the presence of natural surface occupying up to $50 \%$ in the case of I4 examples, while in ten hand-axes, the natural surface occupied $5 \mathrm{I}-75 \%$ of face 2 .

To characterise the morphology of the hand-axes from Khor Shambat, the method of typological classification was used, proposed by Bordes (I96I) and consisting of the calculation of ratios of various dimensions. Only complete specimens and those with a slightly broken tip ( 23 specimens) were measured. As a result of measurements, nearly a half of the hand-axes were classified as cordiform (II specimens, 48\%), the forms of the remaining ones are triangular (four specimens, I7\%), subtriangular (three specimens, I3\%), subcordiform (two specimens, 8\%), limande (two specimens, 8\%) and ovate (one specimen, $4 \%$ ). The distribution of hand-axes from Khor Shambat within the four shape zones of Bordes is presented in Fig. I3. The analyses of the cross sections of the hand-axes and the cleaver indicated that lenticular cross sections (I2 specimens, $48 \%$ ) and plano-convex (six specimens, 24\%) ones predominate with individual backed, angular, rhombus and trapeze cross sections.

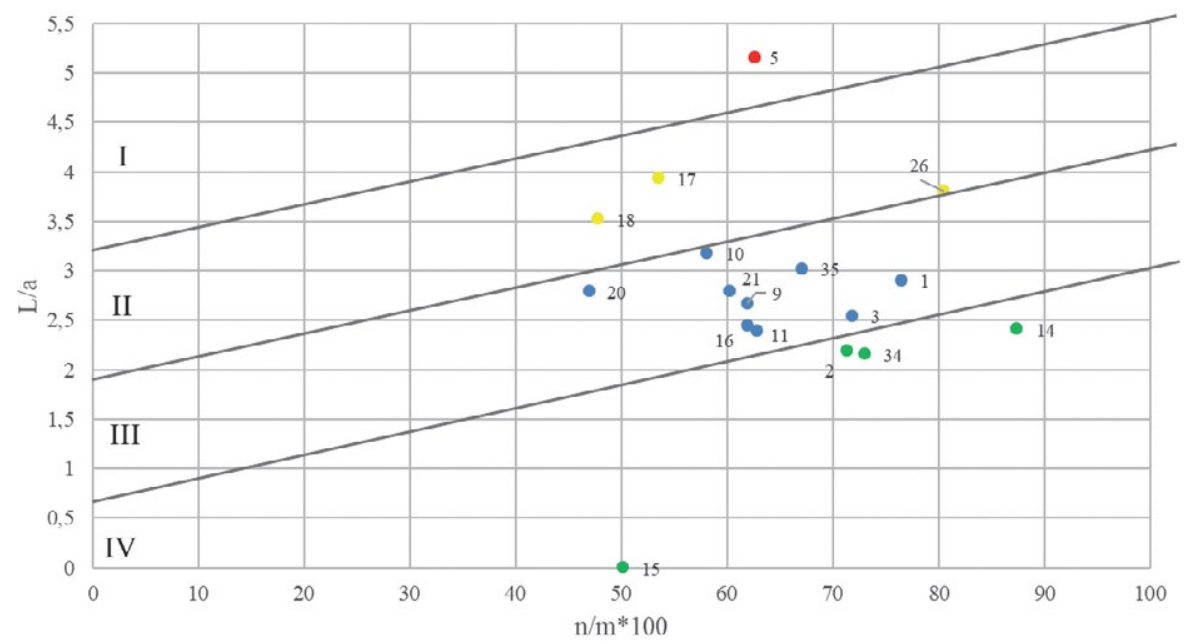

Fig. 13. A scatterplot presenting the distribution of Khor Shambat hand-axes according to Bordes' (I96I) shape zones. Graphic design: G. Michalec. 
54 Mirostaw Masojć, Amel Hassan Gismallah, Grzegorz Michalec, Andrzej Gataś and Maciej Jórdeczka

To sum up, the most common shape of the hand-axe from Khor Shambat is cordiform with lenticular cross section made on a stone chunk. The average sizes are $c .170 \mathrm{~mm}$ in length, $100 \mathrm{~mm}$ in width and $40 \mathrm{~mm}$ in thickness, while the average weight does not exceed $\mathrm{I} \mathrm{kg}$. Face I and 2 display on average a dozen or so scars and occasional bifacial retouch, while the natural surface does not exceed 50\% of face I and remains within the range of $25-75 \%$ in the case of face 2.

\section{Geometric-morphometric comparative analysis}

The hand-axes from Khor Shambat were subject to a morphometric analysis together with the assemblage from two nearby Acheulean sites: the Dakhla Oasis in Egypt (Schild and Wendorf I977) and EDAR 133 in Sudan (Masojć et al., 2019). The geometric-morphometric approach to $2 \mathrm{D}$ objects aimed at determining the differences between the assemblages of Acheulean artefacts. The geometric-morphometric, or morphometric, method has been used in archaeology, e.g., to analyse assemblages of pebble and biface tools from the early and middle Pleistocene (Lycett 2007; 2008; Costa 20I0; Serwatka 20I4) as well as late-Pleistocene tanged points (Serwatka and Riede 20I6; Serwatka 20I8). Our analysis implemented a pattern similar to that used by Costa (2010) in the research of middle-Palaeolithic bifacial tools from site Castel di Guido.

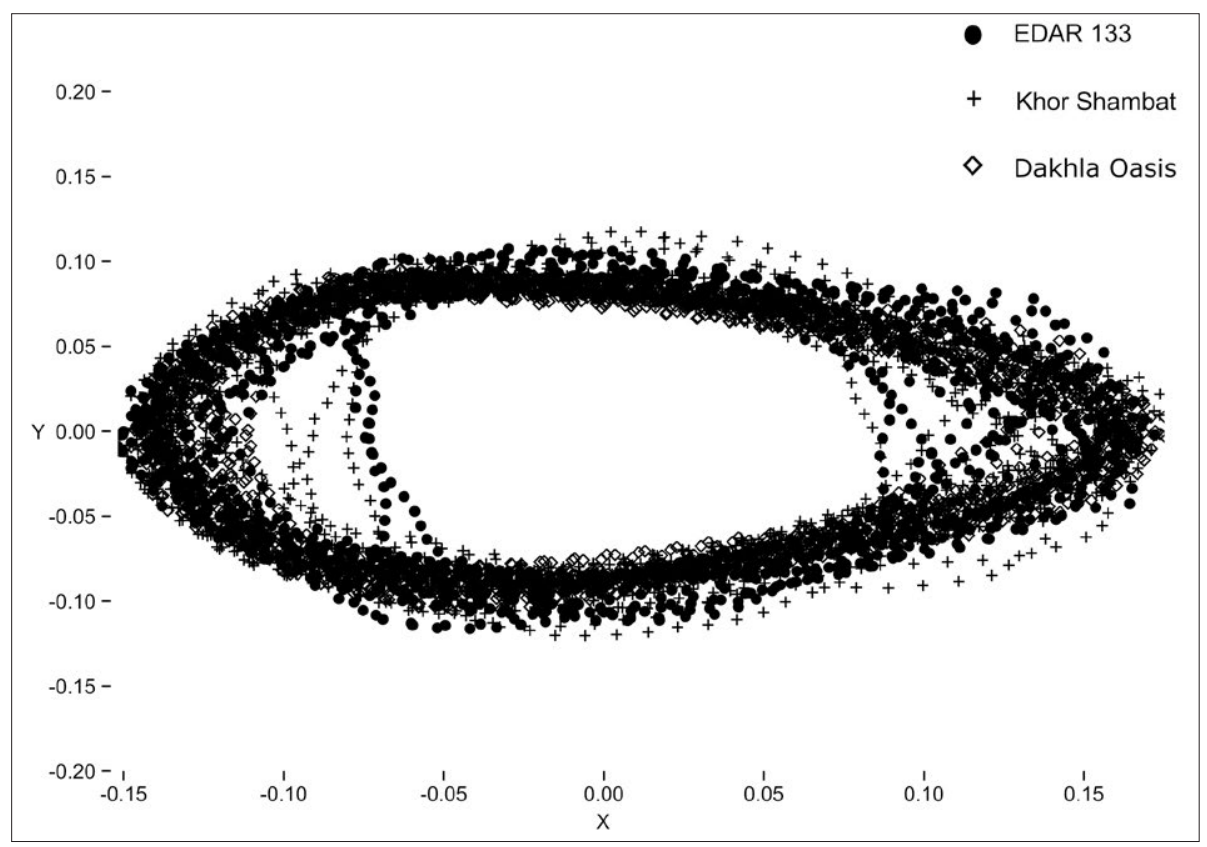

Fig. I4. Results of Procrustes adjusting for 66 hand-axes from the three analysed sites $(3 \times 22)$. Graphic design: G. Michalec. 
Twenty two hand-axes (completely preserved or with a slightly broken tip) were selected from each site. In the case of the tools from Khor Shambat and EDAR 133, the photographs of the artefacts were made in Sudan and were used to draw their outlines. The drawings of the artefacts from the Dakhla Oasis in Egypt (Schild and Wendorf 1977) were scanned. The orientation of photographs and outlines were made with the use of a vector graphics programme - Inkscape. The hand-axes were oriented along the axis of symmetry going through the tip and the middle of the base (McPherron and Dibble 1999); the outlines of the artefacts were drawn with a tool for drawing a Bézier curve.

The tpsUtil 64 program was used to convert files from the JPG to TPS formats; the tpsDig 2 program with the use the tools of automatic outlining was used to mark 75 landmarks on each object. All the XY coordinates of the landmarks in the Cartesian coordinate system were generated in tabular form for analysis by the PAST 3 (PAleontological STatistics) program. The acquired data were subject to Procrustes superimposition, which aims at generating an average shape of all $2 \mathrm{D}$ objects in the central point of the component axis (points 0.0; Fig. I4). All the averaged values were analysed with the use of the principal component analysis (PCA), while MANOVA (Pillai 2014) and PERMANOVA statistical tests (Anderson 20I7) were used to examine 25 landmarks proportionately selected from each object. In this way we were able to verify the possibility of occurrence of a significant statistical difference between the assemblages. The use of permutation multivariate analysis of variance (PERMANOVA) to confirm the results of the first test (MANOVA) resulted from the specific character of the former; it does not have to meet the requirement of normality of distribution, it is resistant to homogeneity of variances and it also examines distances between particular units of observation and centroids and not the mean values of individual groups (Anderson 2017).

\section{Results}

Principal component analysis (PCA) results reveal that over $95 \%$ of variances are described by the first 6 main elements, of which the first 2 reached a value of 39.475 and 32.322 (Table 3). Due to the highest values of the first two components, the results of the analysis were presented with the emphasis on these values.

The analysis of thin-plate deformation shows the diversification of the shape of the artefacts in the examined assemblages. The axis of the main component I displays the shapes approximating to classic almond-shaped and irregular forms, while the axis of the main component 2 presents triangular/subtriangular and oval forms (Fig. I5). Most artefacts have a shape approximating to subtriangular and almond-shaped forms, which is especially distinct in the case of the assemblage from the Dakhla Oasis. The remaining two assemblages mainly have a shape approximating to classic almondshaped, irregular and - in few cases - oval forms. The irregularity of the shape of the artefacts from site EDAR 133 may result mainly from the fact that tips of hand-axes 
56 Mirostaw Masojć, Amel Hassan Gismallah, Grzegorz Michalec, Andrzej Gataś and Maciej Jórdeczka

Table 3. Percentage values of variances described by the first io main components.

\begin{tabular}{|c|c|c|c|}
\hline $\begin{array}{c}\text { Principal } \\
\text { component }\end{array}$ & Eigenvalue & \% variance & Cumulative \% variance \\
\hline 1 & 0.0109379 & 39.475 & \\
\hline 2 & 0.00923296 & 33.322 & 72.797 \\
\hline 3 & 0.00410937 & 14.831 & 87.628 \\
\hline 4 & 0.0011541 & 4.165 & 91.793 \\
\hline 5 & 0.000670015 & 2.418 & 94.211 \\
\hline 6 & 0.000289021 & 1.043 & 95.254 \\
\hline 7 & 0.000259375 & 0.936 & 96.191 \\
\hline 8 & 0.000191735 & 0.692 & 96.882 \\
\hline 9 & 0.000126516 & 0.457 & 97.339 \\
\hline 10 & $9.16525 \mathrm{E}-05$ & 0.331 & 97.670 \\
\hline
\end{tabular}

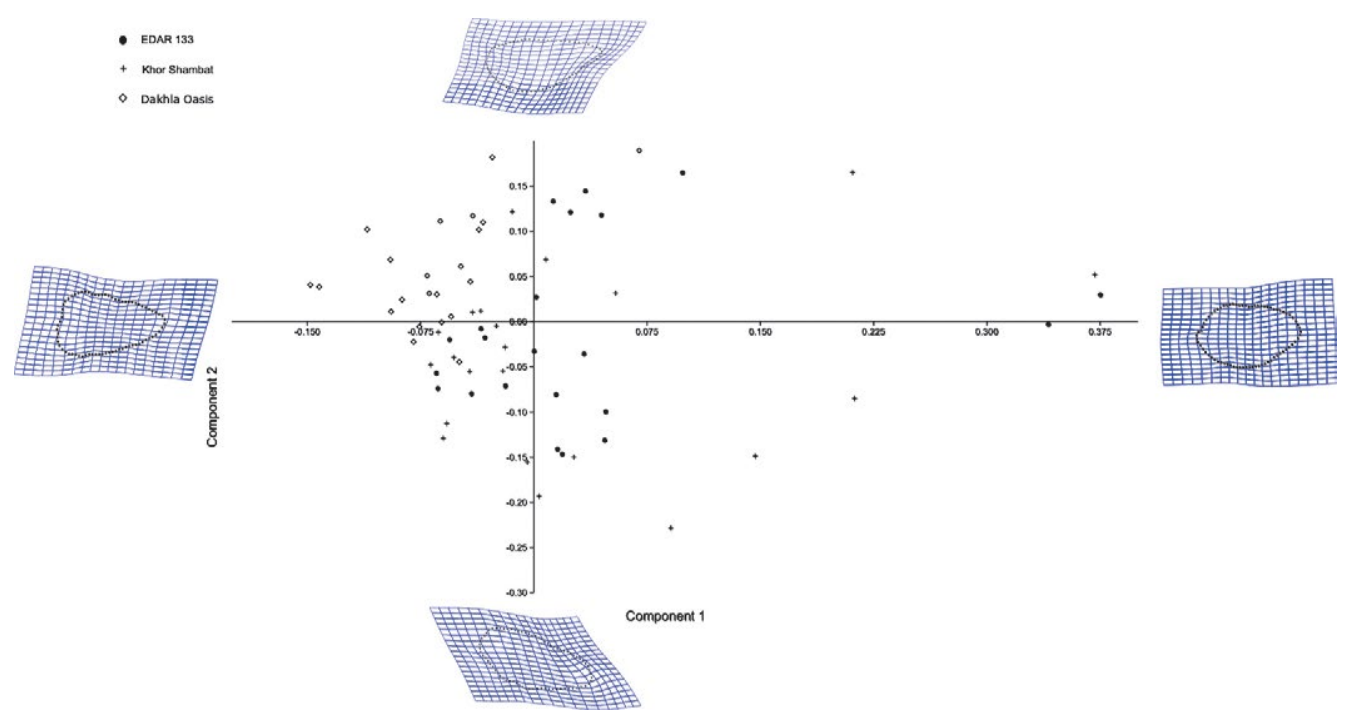

Fig. 15. Plot of the PCA scores for main components I and 2 with marked transformations for extreme values of both axes. Graphic design: G. Michalec. 


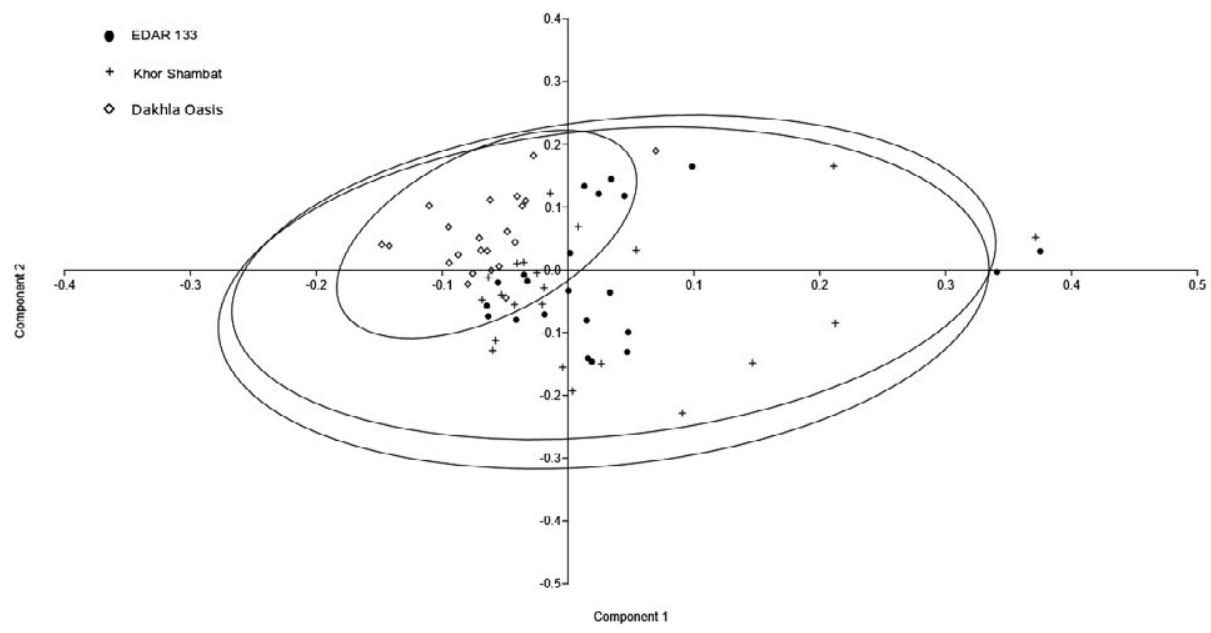

Fig. I6. Range of adjustment of variation $95 \%$ for each assemblage of artefacts in PCA. Graphic design: G. Michalec.

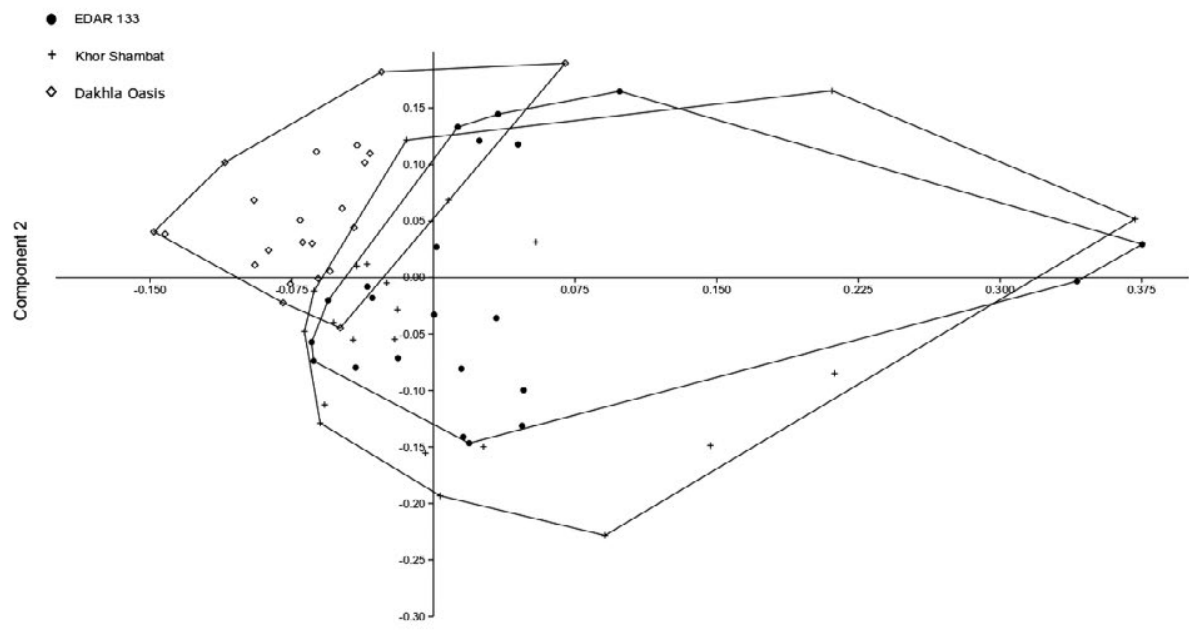

Component 1

Fig. 17. Plot of the PCA scores with convex outlines for individual groups of artefacts. Graphic design: G. Michalec. 
Table 4. PERMANOVA results with the comparison in pairs of sites:

(KHS) Khor Shambat, (ED 133) EDAR 133, (DO) Dakhla Oasis.

\begin{tabular}{|l|c|c|c|}
\hline & KHS & ED 133 & DO \\
\hline KHS & - & 0.3308 & 0.0001 \\
\hline ED 133 & 0.3308 & - & 0.0001 \\
\hline DO & 0.0001 & 0.0001 & - \\
\hline
\end{tabular}

\begin{tabular}{|l|l|}
\hline \multicolumn{2}{|l|}{ PERMANOVA } \\
\hline Permutation N & 9999 \\
\hline Total sum of squares & 0.5979 \\
\hline Within-group sum of squares & 0.4546 \\
\hline F & 9.926 \\
\hline p (same) & 0.0001 \\
\hline
\end{tabular}

were made with blows forming I or 2 opposite notches. Similar forms are known from the early-Acheulean site Olduvai George from Tanzania (de la Torre and Mora 20I8).

Most units of observation subject to PCA are in the range of $95 \%$, which testifies to a small number of outliers in the results of the analysis (Fig. I6). The position of units of observation in the assemblages of hand-axes from the Dakhla Oasis is accumulated in the small area of the diagram, which proves the great extent of standardisation of shape of the objects. In the case of tools from EDAR 133 and Khor Shambat, the units of observation are considerably dispersed, while convex outlines show similarities between them (Fig. 17). There is a distinct diversity between the Dakhla Oasis and the two remaining sites.

\section{Manova/Permanova}

The results of the Mardia Kurtosis test of normality proved the absence of normality of distribution for all variables ( $p=5.357 \mathrm{E}-\mathrm{IO})$; in this case we had to implement MANOVA with Pillai's trace. The MANOVA revealed a distinct diversity between the groups (Pillai's trace $=\mathrm{I} .8 \mathrm{II}, \mathrm{F}=2.869, \mathrm{p}=0.0007774$ ), which is also visible in the results of PERMANOVA (Table 4). Results of comparison in pairs confirm the similarity of hand-axes between EDAR 133 and Khor Shambat and difference between these two assemblages and the artefacts from the Dakhla Oasis, which is identical with the PCA result. 
Acheulean Bifaces from Khor Shambat, Omdurman (Sudan), Comparative Studies in the Nubian Context

\section{The implications of the comparative analysis}

The results of the analysis prove a considerable similarity between the assemblage from Khor Shambat and the artefacts from site EDAR 133 and a distinct difference from the Dakhla Oasis material. Differences in sizes and shape of the artefacts may result from the exploitation of different local raw material. In the case of Dakhla Oasis, the exploited material was chert, the blocks of which are smaller but their quality is very good. At EDAR site 133 mainly quartz and rhyolite were used, whose naturally occurring blocks reach considerable dimensions, and at site Khor Shambat it was Nubian quartzitic sandstone of worse flaking properties, which might have caused the adaptation of the cultural tradition to the quality of the raw material.

The difference may also result from the different chronologies of the assemblages. The presence of Levallois artefacts and oval-shaped hand-axes approximating to Sangoan ones at the Khor Shambat and EDAR 133 sites may indicate their younger chronology in relation to the Dakhla Oasis.

\section{THE KHOR SHAMBAT ACHEULEAN IN BROADER SUDANO-EGYPTIAN CONTEXT}

The presence of Acheulean material in the Nile valley and the desert areas north of the Ethiopian Highlands is confirmed only from the middle Pleistocene. The Acheulean site in Khor Abu Anga, discussed by Arkell (1949), is one of the earliest excavated sites in the Nile valley. Despite considerable erosion, part of the Acheulean material was found there in its original stratigraphic position. The latest monograph has proposed the chronology for Acheulean from this site as between 350-223 ka and for the Sangoan, sub-Saharan industrial complex of equatorial Africa as between 250-150 ka (Carlson 20I5: 132-I34). It should be noted that this chronology is based on the conclusions concerning the chronology of other dated sites from this part of Africa, and mainly the site from the island of Sai on the Nile in Sudan. A sequence of layers with Acheulean material is known from this island, situated between the second and the third cataracts in Nubia, where late assemblages from that culture were adjacent to layers containing the oldest products from the Middle Stone Age, known as the so-called Sangoan. The horizon with Acheulean material was covered by the deposits dated by OSL to $223 \pm 19 \mathrm{ka}$ (Van Peer et al., 2003). Until recently, it was the only dating available for the Acheulean in Sudan. The chronology of the recently discovered Acheulean sites in the Eastern Desert in Sudan is close to those for Acheulean horizons at Sai. At the EDAR 135 site, the upper horizon (Unit IIA) of occurrence of Acheulean artefacts, recorded at a depth of c. $3 \mathrm{~m}$ from the contemporary surface, was covered by the deposits dated with OSL to $\mathrm{I} 8 \mathrm{I} \pm 28 \mathrm{ka}$, while the deposit situated directly underneath was dated to OSL 23I $\pm 22 \mathrm{ka}$ (Masojć et al., 20I9). 
6o $\mid$ Mirostaw Masojć, Amel Hassan Gismallah, Grzegorz Michalec, Andrzej Gataśand Maciej Jórdeczka

Further up the Nile, a number of Acheulean sites have been discovered in the vicinity of the locality of Wadi Halfa (Wendorf ed. 1968) when the Aswan Dam was constructed. One of these is Arkin 8, where a rich concentration of Acheulean material surrounded by younger - possibly functionally diversified - concentrations (Chmielewski 1968) was discovered under fluvial deposits in an ephemeral wadi. None of the remaining Nubian Acheulean sites from the Nile valley (e.g., Nag Ahmed el Khalifa) is situated in its original position (Vermeersch et al., 2000; Vermeersch 200I). A promising area for the research of this culture is al-Jamrab on the White Nile, where Acheulean artefacts have recently been discovered in Pleistocene deposits (Spinapolice et al., 2018). The Atbara river, a tributary of the Nile, is a watercourse along which Acheulean groups migrated. Their numerous remains, accompanied by the remains of Pleistocene megafauna, were discovered in the vicinity of Khasm el Girba mentioned above in the upper part of the river. This is potentially the area of the oldest human settlement in this part of Africa predating the middle Pleistocene (Abbate et al., 20IO).

In the deserts surrounding the Nile, Acheulean remains are known from oases, paleolakes and desert sources. Pioneering research in northern Nubia was carried out in the Kharga (Caton-Thompson 1952) and Dakhla (Schild and Wendorf 198I) oases. In Dakhla, Acheulean material came from the vicinity of an artesian source forming a small lake with warm water surrounded by vegetation. Analogous Acheulean evidence was discovered in the Bir Sahara depression, where artesian wells with accompanying Acheulean material occurred at site BS-14 (dated to $c$. $310 \mathrm{ka}$ ). The accompanying faunal remains, which included ostrich and donkey or zebra, point to a savannah landscape (Schild and Wendorf 198r; Hill and Schild 2017).

Considering the remarks above, the Acheulean material from Khor Shambat discussed in this work should be connected with the activity of hominines of the middle Pleistocene. Bearing in mind that we are confronted with a non-homogeneous assemblage, the multi-stage nature of Acheulean activity in Khor Shambat cannot be ruled out. The available data are not sufficient to justify suggesting the presence of Sangoan material in Khor Shambat, even though a possible indicator of this is the forms of individual oval hand-axes. This unit, similarly as well as another - Lupemban - is in the authors' view present in neighbouring Khor Abu Anga (Carlson 2015). Their chronology was determined on the basis of the chronology from the island of Sai (Van Peer etal., 2003). In this view, the broad chronology of the Acheulean proposed for Khor Abu Anga by Carlson might potentially be applicable to Khor Shambat, and fall within the range of $350-200 \mathrm{ka}$. 
Acheulean Bifaces from Khor Shambat, Omdurman (Sudan), Comparative Studies in the Nubian Context

\section{REFERENCES}

Abbate, E., Albianelli, A., Awad, A., Billi, P., Bruni, P., Delfino, P., Ferretti, M. P., Filippi, O., Gallai, G., Ghinassi, M., Lauritzen, S. E., Lo Vetro, D., Martínez-Navarro, B., Martini, F., Napoleone, G., Bedri, O., Papini, M., Rook, L. and Sagri, M. 2oro. Pleistocene Environments and Human Presence in the Middle Atbara Valley (Khashm el Girba, Eastern Sudan). Palaeogeography, Palaeoclimatology, Palaeoecology 292: $12-34$.

Anderson, M. J. 20I7. Permutational Multivariate Analysis of Variance (PERMANOVA). Wiley StatsRef: Statistics Reference Online. New York, John Wiley \& Sons.

Arkell, A. J. 1949. The Old Stone Age in the Anglo-Egyptian Sudan. Sudan Antiquities Service Occasional Papers I. Khartoum.

Bordes, F. 196r. Typologie du Paléolithique ancien et moyen. Bordeaux, Imprimeries Delmas.

Carlson, R. L. 2015. Khor Abu Anga and Magendobli: Stone Age sites at the Sudanese Nile. Oxford. British Archaeological Reports International Series S2768.

Caton-Thompson, G. 1952. Kharga Oasis in Prehistory. Athlone Press.

Chmielewski, W. 1968. Early and Middle Paleolithic Sites near Arkin, Sudan. In F. Wendorf (ed.), The Prehistory of Nubia v. I, IIO-47. Fort Burgwin Research Center and Southern Methodist University Press.

Costa, A. G. 20Io. A geometric morphometric Aassessment of plan shape in bone and stone Acheulean bifaces from the Middle Pleistocene site of Castel di Guido, Latium, Italy. In S. Lycettand and P. Chauhan (eds), New Perspectives on Old Stones, 23-4I. New York, Springer.

Goren-Inbar, N., Alperson-Afil, N., Sharon, G. and Herzlinger, G. 20I8. The Acheulian Site of Gesher Benot Ya'aqov Volume IV: The Lithic Assemblages. Dordrecht, Springer.

Goren-Inbar, N. and Saragusti, I. I996. An Aheulean biface assemblage from the site of Gesher Benot Ya'aqov, Israel: Indication of African affinities. Journal of Field Archaeology 23: 15-30.

Hill, C. L. and Schild, R. 2017. Paleohydrology and Paleoenvironments at Bir Sahara: Pleistocene Lithostratigraphy and Sedimentology in the Southern Egyptian Sahara. Journal of African Earth Sciences 136: 20I-I5.

Idris, G. 1994. Die Altsteinzeit im Sudan. Bonn. Archäologische Berichte 4.

Jórdeczka, M., Chłodnicki, M., Sobkowiak-Tabaka, I. and Stanaszek, Ł. M. 202o. Rebirth in the afterlife. Neolithic pot burials from the Khor Shambat, Sudan. Azania: Archaeological Research in Africa 55: I-25. https://doi.org/10.1080/0067270X.2020.1721840

Lycett, S. J. 2007. Is the Soanian Techno-Complex a Mode I or Mode 3 phenomenon? A morphometric assessment. Journal of Archaeological Science 34(9): I434-I440.

Lycett, S. J. 2008. Acheulean variation and selection: does handaxe symmetry fit neutral expectations? Journal of Archaeological Science 35(9): 2640-2648.

Masojć, M., Nassr A., Kim, J. Y., Krupa-Kurzynowska, J., Sohn, Y. K., Szmit, M., Kim, J. Ch., Kim, J. S., Choi, H. W., Wieczorek, M. and Timmermann, A. 2019. Saharan green corridors and Middle Pleistocene hominin dispersals across the Eastern Desert, Sudan. Journal of Human Evolution I30: I4I-I5O. https://doi.org/10.1016/j.jhevol.2019.01.004

McPherron, S. P. and Dibble, H. L. 1999. Stone tool analysis using digitized images: examples from the Lower and Middle Paleolithic. Lithic Technology 24(I): 38-52.

Pillai, K. C. S. 20I4. Multivariate Analysis of Variance (MANOVA). Wiley StatsRef: Statistics Reference Online. New York, John Wiley \& Sons. 
Robertson Research Group, 1988. Geological Map of Sudan I:I 000 000, sheet Khartoum. Khartoum Research Authority of the Sudan.

Schild, R. and Wendorf, F. 1977. The Prehistory of Dakhla Oasis and adjacent desert. Wroclaw, Cracow, Warsaw, Gdansk, Ossolineum, Polish Academy of Sciences.

Schild, R. and Wendorf, F. 1981. The Prehistory of an Egyptian Oasis. A Report of the Combined Prehistoric Expedition to Bir Sahara, Western Desert, Egypt. Wroclaw, Cracow, Warsaw, Gdansk, Ossolineum, Polish Academy of Sciences.

Serwatka, K. 20I4. Shape variation of Middle Palaeolithic bifacial tools from southern Poland: a geometric morphometric approach to Keilmessergruppen handaxes and backed knives. Lithics: the Journal of the Lithic Studies Society 35: I8-32.

Serwatka, K. 20I8. What's your point? Flexible projectile weapon system in the Central European Final Palaeolithic. The case of Swiderian points. Journal of Archaeological Science: Reports 17: 263-278.

Serwatka, K. and Riede, F. 2016. 2D geometric morphometric analysis casts doubt on the validity of large tanged points as cultural markers in the European Final Palaeolithic. Journal of Archaeological Science: Reports 9: 150-159.

Spinapolice, E. E., Zerboni, A., Meyer, M. and Usai, D. 20r8. Early Human Occupation at al-Jamrab (White Nile Region, Central Sudan): A Contribution to the Understanding of the MSA of Eastern Africa. Journal of African Archaeology 16: 193-209.

de la Torre, I. and Mora, R. 20I8. Technological behaviour in the early Acheulean of EFHR (Olduvai Gorge, Tanzania). Journal of Human Evolution I20: 329-377.

Van Peer, P., Fullagar, R., Stokes, S., Bailey, R. M., Moeyersons, J., Steenhoudt, F., Geerts A., Vanderbeken T., De Dapper, M. and Geus, F. 2003. The Early to Middle Stone Age transition and the emergence of modern human behaviour at site 8-B-11, Sai Island, Sudan. Journal of Human Evolution 45: 187-193.

Vermeersch, P. M. 200I.'Out of Africa' from an Egyptian Point of View. Quaternary International 75: IO3-II2.

Vermeersch, P. M., Paulissen, E., Otte, M. and Gijselings, G. 2000. Acheulean at Nag Ahmed el Khalifa. In P. M. Vermeersch (ed.), Palaeolithic Living Sites in Upper and Middle Egypt, 57-74. Leuven University Press.

Wendorf, F. (ed.). 1968. The Prehistory of Nubia. Fort Burgwin Research Center and Southern Methodist University Press.

Whiteman, A. J. 1971. The Geology of the Sudan Republic. Oxford, Clarendon Press. 